\title{
HYPOGLYCEMIC EFFECT OF NIGELLA SATIVA L. (RANUNCULACEAE) EXTRACT IN STREPTOZOCIN (STZ) INDUCED DIABETIC RATS
}

Laxmi Shrestha, ${ }^{1}$ Amit Kumar Shrivastava, ${ }^{1}$ Bishal Joshi, ${ }^{2}$ Buddhi Raj Pokhrel ${ }^{3}$ Shanti Gurung, ${ }^{1}$ Nabin Rayamajhi, ${ }^{3}$ Narayan Gautam ${ }^{3}$

\section{ABSTRACT}

\section{INTRODUCTION}

Diabetes mellitus is the most common metabolic disease worldwide. Nigella sativa also known as black cumin, is an emerging miracle herb with a rich historical and religious background. In the present study, we have attempted to study the hypoglycemic effect of aqueous extract of Nigella sativa on diabetes-induced rats.

\section{MATERIAL AND METHODS}

This preclinical study was conducted in Department of Pharmacology from August to October 2019. In this study, hyperglycemia was induced by a single intraperitoneal dose of $60 \mathrm{mg} / \mathrm{kg}$ streptozocin in $0.1 \mathrm{M}$ citrate buffer ( $\mathrm{pH} 4.5$ ). Animals were divided into five groups containing normal control, negative control, standard, test-1, and test-2. The aqueous extract of Nigella sativa was administered 400 and $800 \mathrm{mg} / \mathrm{kg}$ per oral in both the test groups for 18 days. Blood glucose level was measured at three-days interval by glucometer. Oral glucose tolerance test was done by administrating 2 $\mathrm{gm} / \mathrm{kg}$ per oral glucose and the blood glucose was recorded every two-hours interval for eight hours.

\section{RESULTS}

An oral glucose tolerance test showed a decrease in blood glucose level at the dose of 400 and $800 \mathrm{mg} / \mathrm{kg}$ compared to the negative control group. The administration of aqueous extract of Nigella sativa for 18 days showed significant decrease in blood glucose level ( $p=0.001)$ compared to negative control group. The blood glucose level in test $1(400 \mathrm{mg} / \mathrm{kg}) \mathrm{was}$ significantly reduced compared to the standard group $(p<0.001)$. The blood glucose level in test 2 at $18^{\text {th }}$ day was less significant $(p<0.05)$ compared with standard group and test $1(p<0.01, p<0.001)$.

\section{CONCLUSION}

The findings of the present study indicate that the aqueous extract of Nigella sativa has significant hypoglycemic effect in Wistar rats.

KEYWORDS Diabetes mellitus, Nigella sativa, Streptozocin.

1. Department of Pharmacology, Universal College of Medical Sciences, Rupandehi, Bhairahawa, Nepal

2. Department of Physiology, Universal College of Medical Sciences, Rupandehi, Bhairahawa, Nepal

3. Department of Biochemistry, Universal College of Medical Sciences, Rupandehi, Bhairahawa, Nepal

DOI: http//doi.org/10.3126/jucms.v8i02.34284

\author{
For Correspondence \\ Dr. Laxmi Shrestha \\ Department of Pharmacology \\ Universal College of Medical Sciences \\ Bhairahawa, Nepal \\ Email:drshresthalaxmi@gmail.com
}




\section{INTRODUCTION}

Diabetes Mellitus (DM) is the leading cause of death worldwide, with an ever-increasing prevalence. ${ }^{1-3} \mathrm{DM}$ is a group of metabolic diseases characterized by hyperglycemia resulting from defects in insulin secretion, insulin action or both. ${ }^{4,5}$ Current therapies for DM have many shortcomings, including inadequate efficacy and adverse effects which have prompted to extend the pharmacological research towards traditional herbal plants. ${ }^{6-9}$

Nigella sativa, an annual plant commonly grown in Europe, the Middle East, and Western Asia, also known as black seed or black cumin, has been used to treat various diseases such as bronchial asthma, headache, dysentery, infections, hypertension and DM., ${ }^{7,10,11}$ Due to its ability to decrease blood glucose and improve lipid profile, Nigella sativa has garnered much interest in the scientific community. ${ }^{9,12,13}$

Many studies have suggested promising antidiabetic effects of various extracts of Nigella sativa in diabetes-induced rats. ${ }^{8,9,14}$ Many animal studies as well as clinical trials have postulated that Nigella sativa has extra-pancreatic actions, and effects in decreasing oxidative stress, preserving islets of Langerhans cells, and alleviating insulin resistance. ${ }^{14-16}$

The present study aims to measure serum glucose levels in streptozocin induced diabetic rats after fixed doses of Nigella sativa extract and compare the findings with the standard treatment group, control group, and negative control group.

\section{MATERIAL AND METHODS}

The study was conducted from August 2019 to October 2019 in the Department of Pharmacology, Universal College of Medical Sciences (UCMS), Bhairahawa, Nepal, with the approval of Institutional Review Committee (IRC) (Regd. No. UCMS/IRC/186/18). All the experimental protocols were in compliance with the ethical standards and guidelines provided by the Nepal Health Research Council (NHRC), Kathmandu, Nepal.

\section{Preparation of aqueous extract of Nigella sativa (AENS)}

Nigella sativa seed was bought from Bhairahawa local market, Rupendehi, Nepal. Pratikshya Chalise, Research Superintendent, National Herbarium and Plant Laboratories, Godavari, Lalitpur, Kathmandu authenticated and reconfirmed the seeds (registration No 165). The Nigella sativa seeds were ground into coarse powder and weighed quantity was placed in maceration flask, adding sufficient distilled water (1:5). It had been kept with occasional shaking at $4^{\circ} \mathrm{C}$. Complete maceration process took about 72 hours to complete. The menstruum was collected, evaporated, and the extract was obtained once the maceration process had been completed. The percentage yield was calculated and stored at $4^{\circ} \mathrm{C}$ in an airtight container for further use. ${ }^{17}$

$$
\begin{gathered}
\% \text { yeild }=\frac{\text { (weight of extract) } \mathrm{X} 100}{(\text { Weight of Powder) }} \\
\% \text { yield }=\frac{30 \mathrm{~g} \mathrm{X} 100}{550} \\
\% \text { yield }=5.45
\end{gathered}
$$

\section{Experimental animals care}

Adult Wistar rats weighing about (150-200 g) were purchased from Vanaspati Bivag, Kathmandu, Nepal. All animals were housed in animal house facility of Universal College of Medical Sciences (UCMS), Bhairahawa, Rupendehi, Nepal and were maintained at a standard room temperature of $25 \pm 1^{\circ}$ $\mathrm{C}$ and relative humidity of $45-55 \%$. The '12-hour' light and the dark cycle were maintained for seven days with free access to standard diet and water under hygienic condition. The animals had been used for the research after one week of adaptation.

\section{Induction of diabetes and animals grouping}

Hyperglycemia was induced by a single intraperitoneal (IP) dose of freshly prepared $60 \mathrm{mg} / \mathrm{kg}$ streptozocin in $0.1 \mathrm{M}$ citrate buffer ( $\mathrm{pH} 4.5)$ to an overnight fasted rat. A total of 25 experimental animals were included in the study and divided into five groups, randomly (each group containing $n=5$ rats). The group 1 was normal control (taking standard diet only); group 2 was negative control (STZ induced diabetic rats), group 3 was standard (taking metformin $500 \mathrm{mg} / \mathrm{kg}$ ), group 4 as test- 1 and group 5 as test-2, receiving 400 and $800 \mathrm{mg} / \mathrm{kg}$ body weight of Nigella sativa aqueous extract respectively. The blood sample was obtained from the lateral tail vein and saphenous vein after three days of administering STZ. Glucometer (Viva check inc, USA) was used to test the blood glucose level.

\section{Oral glucose tolerance test on experimental animals}

A standard diet was given to the normal control group. Test groups $(\mathrm{T} 1, \mathrm{~T} 2)$ received 400 and $800 \mathrm{mg} / \mathrm{kg}$ per oral dose of Nigella sativa extract, respectively. The standard group received $500 \mathrm{mg} / \mathrm{kg}$ metformin. The initial blood glucose was measured using a glucometer and considered to be zero hours, and then $2 \mathrm{gm} / \mathrm{kg}$ glucose was administered orally to all the experimental groups. The blood glucose level was checked at different time intervals $(2,4$, and 8 hours). The result was compared with the standard group. 


\section{Statistical analysis}

All the grouped data were statistically evaluated, and the results were expressed as the mean \pm SEM. One-way analysis of variance (ANOVA) followed by Tukey's multiple comparison test. $p$-value of $<0.05,<0.01,<0.001$ was considered to be statically significant. All analysis was performed by using Graph Pad Prism (5.01 Graph Pad software inc. San Diego, California, United States of America).

\section{RESULTS}

Blood glucose level before and after the induction of hyperglycemia with STZ

Figure 1 presents the mean blood glucose level values of both the control and treatment groups. The streptozocin induced diabetic rats showed a significant increase in blood glucose level. Administration of metformin to the standard group and aqueous extract of Nigella sativa to an experimental group (Test-1 and test-2) resulted in a decrease in blood glucose level compared to the negative control group. The decrease in blood glucose level is significant in standard, test- 1 and test- 2 group compared to the negative control group, but the reduction in blood glucose level in test group was not significant compared to the standard group.

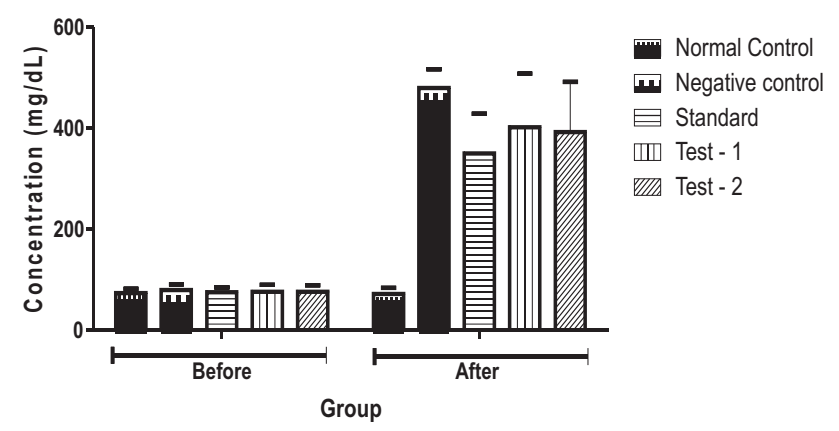

Figure 1. Represent the blood glucose level before and after induction of hyperglycemia with STZ in different groups of Wistar rats

\section{Effects of aqueous extract of Nigella sativa on oral glucose tolerance test in experimental animals}

Comparison of the effect of aqueous extract of Nigella sativa on oral glucose tolerance test (OGTT) is presented in Table 1. The OGTT studies showed a decrease in blood glucose level at the dose of 400 and $800 \mathrm{mg} / \mathrm{kg}$ body weight compared to the negative control group. A decrease in blood glucose level was observed in test-1 (Rats treated with Nigella sativa $400 \mathrm{mg} / \mathrm{kg}$ body weight) and test-2 (rats treated with Nigella sativa 800 $\mathrm{mg} / \mathrm{kg}$ body weight) once a day.
Table 1. The effects of aqueous extract of Nigella sativa on oral glucose tolerance test in experimental animals

\begin{tabular}{llcccc}
\hline S.No & Group & 0 hour & 2 hours & 4 hours & 8 hours \\
\hline 1 & Normal Control & $99.5 \pm 3.61$ & $97.5 \pm 1.82$ & $99.75 \pm 3.14$ & $97.25 \pm 7.08$ \\
2 & Negative control & $98 \pm 1.27$ & $368.5 \pm 25.97$ & $427 \pm 37.76$ & $501.5 \pm 21.13$ \\
3 & Standard & $94.5 \pm 4.47$ & $242.5 \pm 11.52$ & $195.75 \pm 17.81$ & $130.75 \pm 4.30$ \\
4 & Test-1 & $99.5 \pm 5.35$ & $412.75 \pm 26.11$ & $367.25 \pm 21.78$ & $345.75 \pm 3.20$ \\
5 & Test-2 & $113.75 \pm 7.5$ & $437.75 \pm 16.71$ & $347.25 \pm 6.58$ & $295.75 \pm 29.67$ \\
\hline
\end{tabular}

All values were expressed as Mean \pm SEM ** $<0.01$ in one-way Analysis of Variance (ANOVA) with Tukey's multiple comparison test was used for between group differences

The effect of aqueous extract of Nigella sativa on Blood glucose level at a different time period in diabetic rats

Table 2 showed the comparison of blood glucose levels in STZ induced diabetic rats, and Nigella sativa administered experimental animals at a different time interval. Streptozocin induced diabetic rats (Negative control group) showed a highly significant rise in blood glucose level $(505 \pm 34.12$ $\mathrm{mg} / \mathrm{dL}$ at 18 th day) compared to the normal control group $(88.75 \pm 7.11 \mathrm{mg} / \mathrm{dL})$. At third day, the blood glucose level was higher in negative control group (468.75 $\pm 54.16 \mathrm{mg} / \mathrm{dl})$, standard group $(355 \pm 56.23 \mathrm{mg} / \mathrm{dl})$, test-1 (274.5 \pm 68.59 $\mathrm{mg} / \mathrm{dl})$, and test-2 $(464.25 \pm 59.20 \mathrm{mg} / \mathrm{dl})$ than normal control group $(82 \pm 5.61)$. After administration of aqueous extract of Nigella sativa for 18 days to diabetic rat in test-1 (126.25 $\pm 50.49 \mathrm{mg} / \mathrm{dl})$, test-2 $(165.25 \pm 35.03 \mathrm{mg} / \mathrm{dl})$ and metformin in the standard group $(148.75 \pm 40.30 \mathrm{mg} / \mathrm{dl})$ resulted in a statistically significant reduction in blood glucose level as compared to the negative control group $(505 \pm 34.12)$. The blood glucose level in test-1 group was higher at 12th day, but on the 18th day, the blood glucose level in test-1 $(400 \mathrm{mg} / \mathrm{kg})$ was substantially reduced compared to the standard group. The blood glucose level in test-2 at 18th day was less significant $\left(p^{*}<0.05\right)$ compared with test 1 and standard

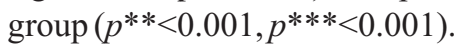

Table 2. Blood glucose level at different time period after treatment with aqueous extract of Nigella sativa

\begin{tabular}{|c|c|c|c|c|c|}
\hline \multirow[b]{2}{*}{ S.No } & \multicolumn{5}{|c|}{ Fasting blood glucose level (mg/dL) } \\
\hline & Group & $3^{\text {rd }}$ Day & $6^{\text {th }}$ Day & $12^{\text {th }}$ Day & $18^{\text {th }}$ Day \\
\hline 1 & Normal Control & $82 \pm 5.61$ & $89.5 \pm 8.97$ & $91.75 \pm 4.49$ & $88.75 \pm 7.11$ \\
\hline 2 & Negative control & $468.75 \pm 54.16^{* * *}$ & $480.25 \pm 72.49^{* * * *}$ & $497 \pm 41.43^{* * *}$ & $505 \pm 34.12^{* * * *}$ \\
\hline 3 & Standard & $355 \pm 56.23^{* *}$ & $198 \pm 73.55^{* *}$ & $170.25 \pm 43.04^{* *}$ & $148.75 \pm 40.30^{* *}$ \\
\hline 4 & Test -1 & $274.5 \pm 68.59^{* * *}$ & $185.75 \pm 43.34^{* * *}$ & $201.75 \pm 75.61^{* * *}$ & $126.25 \pm 50.49^{* * *}$ \\
\hline 5 & Test -2 & $464.25 \pm 59.20^{*}$ & $305.25 \pm 96.75^{*}$ & $221.75 \pm 57.01^{* *}$ & $165.25 \pm 35.03^{*}$ \\
\hline
\end{tabular}

\section{DISCUSSION}

Mother nature is the unlimited storehouse of medicinal plants and Nepal is the country bestowed with the richness of natural resources including variety of medicinal plants. Nigella sativa seeds (black cumin) have been used for the treatment of many clinical conditions including diabetes, hypertension and 
hyperlipidemia for decades. In the present study we observed the hypoglycemic effects of Nigella sativa in Wistar rats.

In the present study, diabetes was induced in rats by single intraperitoneal injection of streptozocin at a dose of $60 \mathrm{mg} / \mathrm{kg}$ body weight. There was significant decrease in blood glucose level compared to the negative control group after oral administration of aqueous extract of Nigella sativa (AENS) at 400 and $800 \mathrm{mg} / \mathrm{kg}$ doses at a various time interval $(3,6,12$, and 18th days). Interestingly, in the present study we found that the dosage of AENS $400 \mathrm{mg} / \mathrm{kg}$ more significantly $(p<0.001)$ reduced blood glucose levels when compared to the higher dose of $800 \mathrm{mg} / \mathrm{kg}(p<0.01)$ of AENS. The possible cause of less effect of $800 \mathrm{mg} / \mathrm{kg}$ may be due to the presence of many other ingredients in the Nigella sativa seeds that produce a counter effect at this higher dose. Similarly, we observed that the blood-glucose-lowering effect of AENS 400 $\mathrm{mg} / \mathrm{kg}$ is quite similar to that of the standard group receiving metformin $(500 \mathrm{mg} / \mathrm{kg})$. Hence, the findings of this study strongly suggest that Nigella sativa may be a remedy of diabetes mellitus as it significantly decreases blood glucose levels in experimental animals. Various similar studies ${ }^{9,10,18}$ are in alignment with the present study as the result of these studies also described a significant reduction on blood glucose level after the administration of Nigella sativa on streptozocin-induced diabetic rats. In a similar study Bano F, et al found that there was a significant reduction in blood glucose level in STZ induced diabetic rats after administration of Nigella sativa for six weeks. ${ }^{19}$ In an open-label randomized clinical trial Moustafa HAM, et al concluded that administration of Nigella sativa oil at a dose of $1350 \mathrm{mg}$ per day have a significant effect in reduction of fasting blood glucose. $^{20}$

Nigella sativa is used as antidiabetic agent since ancient times. The antidiabetic activity of Nigella sativa is mediated through its multiple pharmacological actions. Nigella sativa exerts its anti-diabetic effects by reducing morphological changes as well as by preserving the integrity of pancreatic beta-cells, thus protecting beta-cells against oxidative stress. ${ }^{21}$ Various other studies have shown an increase in insulin secretion by pancreatic beta cells in concentration-dependent manner ${ }^{22}$ and decrease in blood glucose level due to inhibition of hepatic gluconeogenesis. ${ }^{23}$ Another possible explanation of anti-diabetic effects of Nigella sativa is that, it has direct effect on reducing intestinal absorption of glucose in a dosedependent manner. ${ }^{24}$

\section{CONCLUSION}

This study concludes that there is significant decrease in blood glucose levels in Wistar rats following administration of aqueous extracts of Nigella sativa seeds. This shows the promising effect of AENS to be a potent alternative for the treatment of diabetes mellitus in the future.

\section{LIMITATIONS}

As the sample size of the present study was small, further studies in animals and humans with a large sample size are the demands of the future. More advanced studies are needed for the identification of the specific bioactive compounds of Nigella sativa that are responsible for its anti-diabetic effects.

\section{ACKNOWLEDGEMENT}

We are thankful to Universal College of Medical Sciences, Bhairahawa, Nepal for providing a grant to conduct this experiment. We are also grateful to the working staff of the Department of Pharmacology for their effort.

\section{REFERENCES}

1. Diabetes 2018 cited 2020 February, 10. Available from: https:// www.who.int/news-room/fact-sheets/detail/diabetes.

2. Cardiovascular Diseases (CVDs) 2017 [cited 2020 February, 10. Available from: https://www.who.int/news-room/factsheets/detail/cardiovascular-diseases-(cvds).

3. WHO. Global Report On Diabetes. 2016.

4. Joshi B, Shrestha L, Bhattarai K, Manandhar N, Mahotra NB. Comparison of central obesity with overall obesity in predicting the risk of type 2 diabetes mellitus. Journal of Universal College of Medical Sciences. 2019;7(1):17-21.

5. DeFronzo RA, Ferrannini E, Groop L, Henry RR, Herman WH, Holst JJ, et al. Type 2 diabetes mellitus. Nature Reviews Disease Primers. 2015;1(1):1-22.

6. Ahn $\mathrm{CH}$, Choi SH. New drugs for treating dyslipidemia: Beyond statins. Diabetes \& Metabolism Journal. 2015;39(2):87-94.

7. Bamosa AO, Kaatabi H, Lebdaa FM, Elq A, Al-Sultanb A. Effect of Nigella sativa seeds on the glycemic control of patients with type 2 diabetes mellitus. Indian J Physiol Pharmacol. 2010;54(4):344-54.

8. Bensiameur-Touati K, Kacimi G, Haffaf E-M, Berdja S, Aouichat-Bouguerra S. In vivo subacute toxicity and antidiabetic effect of aqueous extract of Nigella sativa. Evidence-Based Complementary and Alternative Medicine. $2017 ; 2017$.

9. Sultan MT, Butt MS, Karim R, Zia-Ul-Haq M, Batool R, Ahmad S, et al. Nigella sativa fixed and essential oil supplementation modulates hyperglycemia and allied complications in streptozotocin-induced diabetes mellitus. Evidence-Based Complementary and Alternative Medicine. $2014 ; 2014$. 
10. Balbaa M, El-Zeftawy M, Ghareeb D, Taha N, Mandour AW. Nigella sativa relieves the altered insulin receptor signaling in streptozotocin-induced diabetic rats fed with a high-fat diet. Oxidative Medicine and Cellular Longevity. 2016;2016.

11. El-Dakhakhny M, Mady N, Lembert N, Ammon H. The hypoglycemic effect of Nigella sativa oil is mediated by extrapancreatic actions. Planta Medica. 2002;68(05):465-6.

12. Salama RHM. Hypoglycemic effect of lipoic acid, carnitine and Nigella sativa in diabetic rat model. International Journal of Health Sciences. 2011;5(2):126.

13. Daryabeygi-Khotbehsara R, Golzarand M, Ghaffari MP, Djafarian K. Nigella sativa improves glucose homeostasis and serum lipids in type 2 diabetes: A systematic Review and Metaanalysis. Complementary Therapies in Medicine. 2017;35:613.

14. Le PM, Benhaddou-Andaloussi A, Elimadi A, Settaf A, Cherrah Y, Haddad PS. The petroleum ether extract of Nigella sativa exerts lipid-lowering and insulin-sensitizing actions in the rat. Journal of Ethnopharmacology. 2004;94(2-3):251-9

15. Kanter M, Coskun O, Korkmaz A, Oter S. Effects of Nigella sativa cell damage in streptozotocin induced diabetic rats. The Anatomical Record Part A: Discoveries in Molecular, Cellular, and Evolutionary Biology: An Official Publication of the American Association of Anatomists. 2004;279(1):685-91.

16. Heshmati J, Namazi N, Memarzadeh M-R, Taghizadeh M, Kolahdooz F. Nigella sativa oil affects glucose metabolism and lipid concentrations in patients with type 2 diabetes: A randomized, double-blind, placebo-controlled trial. Food Research International. 2015;70:87-93.

17. Benlafya K, Karrouchi K, Charkaoui Y, El Karbane M, Ramli Y. Antimicrobial activity of aqueous, ethanolic, methanolic, cyclohexanic extracts and essential oil of Nigella sativa seeds. Journal of Chemical and Pharmaceutical Research. 2014;6(8):9-11.

18. Abdelmeguid NE, Fakhoury R, Kamal SM, Al Wafai RJ. Effects of Nigella sativa and thymoquinone o streptozotocin induced diabetic rats. Journal of Diabetes. 2010;2(4):256-66

19. Bano F, Wajeeh M, Baig N, Naz H, Akhtar N. Antiobesity, antihyperlipidemic and hypoglycemic effects of the aqueous extract of Nigella Sativa seeds (Kalongi). Pak J Biochem Mol Biol. 2009;42(4):136-40.

20. Moustafa HAM, El Wakeel LM, Halawa MR, Sabri NA, ElBahy AZ, Singab AN. Effect of Nigella sativa oil versus metformin on glycemic control and biochemical parameters of newly diagnosed type 2 diabetes mellitus patients. Endocrine. 2019;65(2):286-94.
$\mathrm{M} \quad \mathrm{H}$

22. Rchid H, Chevassus H, Nmila R, Guiral C, Petit P, Chokaïri M, et al. Nigella sativa seed extracts enhance glucose induced insulin release from rat isolated Langerhans islets. Fundamental \& Clinical Pharmacology. 2004;18(5):525-9.

23. Fararh K, Atoji Y, Shimizu Y, Shiina T, Nikami H, Takewaki T. Mechanisms of the hypoglycaemic and immunopotentiating effects of Nigella sativa L. oil in streptozotocin-induced diabetic hamsters. Research in Veterinary Science. 2004;77(2) :123-9.

24. Meddah B, Ducroc R, Faouzi MEA, Eto B, Mahraoui L, Benhaddou-Andaloussi A, et al. Nigella sativa inhibits intestinal glucose absorption and improves glucose tolerance in rats. Journal of Ethnopharmacology. 2009;121(3):419-24

21. 